\title{
Zrod nové slovenské literatury v interpretacích'1
}

\author{
Ivo Pospíšil (Brno)
}

Peter Mráz: Interpretácia ako výzva. Analýza textov z obdobia zrodu novodobej slovenskej literatúry. Bratislava: IRIS, 2021. 257 s. ISBN 978-80-8200-073-6.

Při slově „interpretace“ se vždy bojím určité suverénnosti, povrchnosti, vnějškovosti a vědomí, že každý všemu rozumí, když ovládne pár interpretačních postupů. Tato obava se však netýká přítomného svazku, nebot již při letmém nahlédnutí, potvrzeném pak pozornou četbou, je zřejmé, že autor svou látku dobře zná, že se s láskou a kompetencí noří do textů, aniž by ztrácel nutný nadhled a odstup. Přitom jde o klíčové období literatury na Slovensku. Autor uvádí svou monografickou studii obecnějšími úvahami, které se týkají interpretace uměleckého/literárního textu v didaktické praxi, fikčním světem a hranicemi jeho interpretace a interpretací textu optikou recepční estetiky. Nevím, zda bylo nutné psát o fikčních světech a recepční estetice, ledaže by to jinak nešlo kvưli ocenění vládnoucí literárněvědnou komunitou - navíc to jsou věci známé a projevuje se zde to, co v dílech jiných autorů. Slabší je míra propojení těchto obecných partií s vlastní interpretací konkrétních textů. Recepce je ovšem širší pojem než celá recepční estetika; jde také o historicitu, diachronní vnímání literárního artefaktu a jejich proměny v čase a prostoru. Když je řeč o fikčních světech, nelze nedodat, že klíčová díla současné světové literatury nebo lépe světového literárního kánonu se vyskytují na hraně fact a fiction. Nakolik je tato tendence pozorovatelná už v dílech počínající novoslovenské literatury, je ovšem

1 Tento výstup vznikl na Masarykově univerzitě v rámci projektu Mezislovanské kulturni a literárni vazby číslo MUNI/A/1331/2020 podpořeného $\mathrm{z}$ prostředků účelové podpory na specifický vysokoškolský výzkum, kterou poskytlo MŠMT v roce 2021.Původní varianta recenze vyšla v časopise Proudy pod názvem Interpretace restartu novodobé slovenské literatury. Proudy, 2021, č. 1. https://www.phil.muni.cz/journal/proudy/filologie/ recenze/2021/1/pospisil_interpretace_restartu_ novodobe_slovenske_literatury.php\#articleBegin diskutabilní, resp. to, zda tento jev vyrůstá spíše ze synkretického charakteru literatury pozdně renesanční nebo dokonce středověké, nebo je znakem nového syntetického vývoje novodobého. Autor je velmi obezřetný v tom, aby nezapomněl na některé literární vědce - zejména v seznamu literatury - ukázat. Jsou tu v podstatě všichni, kteří se literaturou tohoto období zabývají ze Slováků, ale je tu i známý Mad’ar Kiss Szemán, jistě i Češi - samozřejmě koryfejové, kteří musí být vždy uvedeni. A nejsem si jist, zda by recenzenti nemohli být vybráni alespoň o něco lépe. Sama interpretace je však nápaditá, brilantní. Týká se řady zajímavých děl, z nichž některá stála dlouho interpretačně stranou. Najdeme tu přiležitostnou poezii slovenských evangelíků, Pavla Šramka a jeho Života a smrti požehnaná památka, Michala Semiana, Juraje/Jiř́ího Palkoviče, Bohuslava Tablice, studii o jeho směrovém synkretismu, autorský mýtus Jána Hollého a Šafaříkův sonet, stejně jako Kollárovu Slávy dceru a poezii štúrovců. A potom - last but not least - interpretaci Bohuslava Tablice u Evy Fordinálové a postavu Andreje Sládkoviče v díle Štefana Krčméryho. Kniha má všechny náležitosti výsostné odborné práce, včetně pramenů, sekundární literatury a edičních poznámek; trochu mi tu chybí přinejmenším jmenný, snad i věcný rejstřík. To, co mě vždy na těchto výzkumech překvapovalo, je poměrně malé zření ke komparativním aspektům takové interpretace, zvláště tam, kdy se nabízí to nejjednodušší: česko-slovenský vztah, i když tu může jít i o jev, jenž jsme v našich studiích obsažených v našem syntetickém, na Slovensku nijak nezaznamenaném svazku Slovakistické reflexe ${ }^{2}$ (2017) nazvali „mazání české stopy“, jak

2 POSPÍŠIL, Ivo: Slovakistické reflexe. Brno: Česká asociace slavistů, 2017. 
o něm svědčí některá slovenská literárněvědná díla minulosti - anebo jde prostě o to, že se česká literatura chápe jako domácí anebo se př́liš nestuduje a nezná - ostatně stejně jako slovenská v Čechách a na Moravě (Je například známo, že české vědecké publikace uveřejněné na Slovensku se někdy a někde via facti nepokládají za zahraniční - otázka tedy je, proč jsme kdysi ne zcela dobrovolně vytvořili dva samostatné státy). Př́lišná modernizace výkladu slovenské literatury ve smyslu jakési polouzavřené entity, textově spíše izolované v imanentním okruhu vzájemné korespondence protiřečí otevřenosti doby a vstřícnosti literatury obecně k jiným kulturním okruhům, v krajním případě ve střední Evropě, ale ta vycházela z celoevropských, mediteránních pramenů. Jiný aspekt - srovnávací a genologický - ukazuje Pavol Markovič ve své knize o tomto klíčovém obdobî̉ ${ }^{3}$ řekl bych přímo startu slovenské literatury, když pomineme, že ta podle domácích literárních historiků bere svůj počátek od cyrilometodějského období, ale to je ono zpětné modelování, které známe při rekonstruování slovanského literárního středověku obecně - zde každá slovanská literatura měla svůj autochtonní vývoj a značně se od sebe liší svou kvantitou i kvalitou a také stupněm začlenění do evropských kulturních celků, jak to kdysi barvitě podal Frank Wollman v učebnici vytvořené ještě v Bratislavě o prázdninách 1928 - Slovesnosti Slovanů. Tak, že, jak lehce parafrázujeme, slovanské literatury byly bohatší než literární průměr západoevropský o vlastní hodnoty, že sdílely stejné nebo podobné hodnoty, takže na literární mapě Evropy slovanské oblasti byly by zakresleny asi týmiž antropologickými barvami a týmiž zónami historických epoch a myšlenkových proudů; jen snad by byl rozdíl v stupni barev a v síle pruhů. Ale kromě toho přistupovaly by mezislovanské odstíny barevné a daleko složitější sít vlivů mezislovanských, zvláště v oboru látkovědy a také v typologii. Toto mezislovanské plus není způsobeno jen dědictvím byzantské kultury a ortodoxií, není jen podmíněno více méně organickým zasahováním

3 MARKOVIČ, Pavol: Slovenský literárny klasicizmus a preromantizmus. Prešov: Vydavatel'stvo Prešovskej univerzity v Prešove, 2020. západoevropských vlivů, leč též jejich přijetím, výběrem a způsobem zpracování. ${ }^{4}$

Restart v období vrcholícího středoevropského baroka a za klasicismu se tohoto srovnávacího kontextu nemůže zbavit. Peter Mráz si nicméně $\mathrm{v}$ analýze konkrétních textů počíná velmi kompetentně, s plným poetologickým nasazením a přináší nové poznatky: zejména si cením jeho Palkoviče a Tablice. Pokud jde o Slávy dceru měl by si však také povšimnout knihy Putnovy, která tu není zaznamenána ani v seznamu literatury, když už Kollár píśící česky patří určitě také do české literatury. Pravda je, že se jedná o knihu kultovní, což je dáno mediálním obrazem autora, tu zaslouženým více, tu méně. ${ }^{5}$ A potom je to - v souvislosti s recepční estetikou - průkopnická a často opomíjená studie Františka Kautmana (1927-2016), jež se přímo týká hermeneutiky a interpretace a která je až mrazivě skeptická a kdyby mohla vstoupit do československého prostoru už na konci šedesátých let, kdy byla napsána, a v době, kdy u nás nebylo po moderní, novodobé literární hermeneutice - snad s výjimkou osvícených nemedializovaných jedinců - ani stopy, nebot se sem vracel strukturalismus v nové podobě a v nových alternacích, aby byl poté znovu potlačen, což jsem si drsně vyzkoušel na vlastní badatelské dráze. Kautmanova studie vyšla nakonec až v devadesátých letech v širším souboru, ale to také nebylo na škodu, nebot se ocitla v někdy překvapivých průnicích a kontextech. ${ }^{6}$ Budiž přítomné poznámky brány spíše jako výzva a komplementarita $\mathrm{k}$ tomu objevnému, čeho autor ve své knize dosáhl.

Subjektivně považuji za klíčové a nejdokonaleji zpracované a také nejpodnětnější kapitoly Sonet jako priležitostná báseñ o P. J. Šafárikovi

4 Viz WOLLMAN, Frank: Slovesnost Slovanů (1. vyd. 1928). 2. doplněné a opravené vyd. Eds. Ivo Pospíšil Miloš Zelenka. Brno: Tribun EU, 2012.

5 PUTNA, Martin C.: Ján Kollár: Slávy dcera: Báseň lyricko-epická v pěti zpěvich. Překlad a výklad Slávy dcery z panslavistického mýtu do kulturni historie. Praha: Academia, 2014

6 KAUTMAN, František: $K$ typologii literatury a literárni vědy. Praha: Primus, 1996 (kapitola Hermeneutika a interpretace). 
a Štúrovci v zápase o poéziu; vůbec se zdá, že právě analýza a interpretace poezie je autorovou silnou stránkou, i když ani jeho rozbory prozaických děl nejsou nenápadité. Mrázova kniha je př́nosná vyhraněnou, niterně v textu ukotvenou pozicí a nehledě na uvedené výhrady a alternativní nabídky je v slovenské literární vědě - podle mého soudu - v jistém smyslu událostí.

\section{prof. PhDr. Ivo Pospíšil, DrSc.}

Ústav slavistiky

Filozofická fakulta, Masarykova univerzita

Arna Nováka 1, 60200 Brno, Česká republika

ivo.pospisi@phil.muni.cz 